\title{
Factors Affecting Dividend Policy: Empirical Study from Pharmaceutical's Companies in Pakistan (PSX)
}

\author{
Sajida Gul, Irfan Ullah, Hina Gul and Shahid Rasheed
}

\begin{abstract}
The existing study intends to measure those factors that affect dividend policy by considering pharmasuitacal's companies registered on PSX from 2013 to 2017. Population based on all sectors of Pakistan Stock Exchange (PSX) in which pharmaceutical's companies taken as a sample by using census sampling technique because all companies of pharmaceutical sector were considered. Panel VAR model, fixed effect model (FAM) and also used a regression model to define the influence of IV on DV. The results revealed that has a significant effect of managerial ownership, debt policy, ROA, firm size and free cash flow on dividend policy. The findings of this study demonstrated that the company's future performance has more concern for the betterment investors than current revenue. There should be active focus on the future aspects in order to improve firm performance.
\end{abstract}

Index Terms - Pharmaceutical's Companies, PSE, MO, DP$L E V, R O A, F S, F C F, D P$

\section{INTRODUCTION}

Financial management deals in the management of finance to get the organizational goal. It also increases the value of a company to enhance the worth of stockholders. The responsibility of financial manager is to carefully check the financial decision, asset management decision and dividend policy decision in order to make investment in financial asset of the venture and also a part of financing decision because in which organization want to check that what should be the best financing policy for the success of organization and also proposed dividend by the board of directors in annual general meeting by giving a good image of the venture in-front of stockholders [53] and [61].

According to Ababa, 2011 "Dividend policy refers to the dividend decision that manager of a firm would decide to pay to the investors or a shareholder who is commonly known as dividend per share". When the company pay dividend amount in a continuous way, it is crucial for stockholders to hold shares for longer period of time and this decision is directly related to dividend policy. Payment of dividend to stockholders is very important element for a company to enhance the image of the firm. It will also give an impact on the company's profit. Usually, the firm's pay dividend to stockholders in out of firm's earning and the remaining is transferred to retained earnings. The dividend

Published on October 30, 2020.

Sajida Gul, Abasyn University, Pakistan.

(corresponding e-mail: sajida.gul@abasyn.edu.pk)

Irfan Ullah, Abasyn University, Pakistan.

(e-mail: Irfan.ullah@ abasyn.edu.pk)

Hina Gul, Abasyn University, Pakistan.

(e-mail: hina.gul@abasyn.edu.pk)

Shahid Rasheed, Abasyn University, Pakistan.

(e-mail: shahid.rashid@abasyn.edu.pk) policy also demonstrates the ability of the company to manage capital structure [42]. Dividend payout policy is the most debatable area in the

\section{PRoblem Statement}

Dividend payout policy is the most debatable area in the perspective of corporate finance. According to [13] "dividend policy controversy is one of the ten major unsolved problems of corporate finance which deserves more research in order to increase understanding of the subject".

Most of the researchers took into consideration in this area worldwide but no general results have found yet among them. Despite the above contemplations, it is additionally showed that a few factors affecting dividend payout ratio. For example, if there is an expansion earning of a firm it would be expected and demonstrated that it would likewise expand dividend payout ratio of the organization ([39], [46], [25], [60]) but this relationship is being rejected by [34] studies. Same is the case with debt policy. Some researchers have determined positive association [I] whereas some have found negative relationship [60]. These inconsistent results demand more research that could clarify such relationships.

The current research conducted within a same country and taken a same industry, but incorporating different variables in Pharmaceutical's industry listed on Pakistan stock exchange because several studies worked on the determinants of a dividend policy that are much more in corporate finance no one can take and check the entire factors effect on dividend policy. That's why, current study main focus is to investigate the influence of managerial ownership, debt policy, ROA, firm size, and free cash flow on dividend policy from the period of 2013-2017.

\section{RESEARCH QUESTIONS}

- What are the main factors that affect dividend policy?

- How factors do effect on Dividend Policy?

\section{RESEARCH OBJECTIVE}

The objectives are given below to:

- Find out the main factors that affect the dividend policy in Pakistan.

- Inspect the effect of factors on dividend policy from 2013 to 2017 in Pharmaceutical's companies of listed on Pakistan stock exchange (PSX). 


\section{LITERATURE REVIEW}

Miller and Modigliani [40] theory claimed that the firm's dividend policy and current market value are unrelated as per perfect capital market; number of researchers argued that it is wrong because it is only the assumptions of perfect capital market and presented the assumptions of market imperfection e.g. agency cost, tax consideration, irregular information demonstrated that dividend policy is related to the value of the firm. [23], [17], [43], [2].

\section{A. Dividend Policy}

Droughty [20] and Davies and Pain [19] stated in simple words that profit on the share is given to shareholder's called dividend from the net profit of the firm. This payment can be made in cash form or by giving capital gain (additional share, premium on shares). Those companies that are registered/ listed on stock exchange, they are liable to pay a dividend quarterly and semiannually (Interim Dividend) and the final dividend is paid at the end of financial year of the company. Firm's pay dividend after the deduction of corporate tax [33]. In a current scenario dividend, payment/policy has become a major financing decision in corporate finance [14]. The board of directors decides about the dividend amount that is commonly paid on semiannually, quarterly and yearly basis as per the dividend policy of the firm.

There are three groups of financial researchers that check the impact of dividend policy on fir value. The first group stated that dividend payout ratio and firm value are closely related with each other, because when dividend payout ratio is increased so the firm value is increased [37] \& [38]. The opinion of second group is that share prices are slightly decreased due to increase in dividend payout ratio because of two reasons suggested by [35], [11], both of them argued that the firms' have lack of NPV (Net Present Value) projects while acquiring investment, second lead to higher payment of tax when a firm pays more tax on income against its capital appreciation. On the other hand, the third grouped believed that there has no effect between dividend policy and firm value [57], [31].

\section{B. Managerial Ownership}

Firms give an opportunity to managers to be engaged in share ownership to get equal shareholders wealth. Due to this policy, the manager is expected to be achieved more output in a worthy performance as well as direct at a low dimension. With the establishment of a low dividend, the company will have high retained earnings that lead toward high internal sources of funding to make more investment in the future. But it become the cause of conflict between shareholders and firm because most of the shareholders need high rate dividend against their shares [53].

\section{Debt Policy}

Debt policy is taken into consideration as a second variable in the present study. Which examine that if the company has limited retained earnings, in this case the firm avail more leverage to enhance the debt financing? On the basis this influence, more debts lead toward weak financial position that become the cause of insolvency, due to this condition firms keep more cash for the repayment of debts and interest of creditors do not considered [47].In order to test the factors affecting policy of dividend, the scholars take into consideration that debt policy play a vital role. Most of the past researchers examined that debt has not provided a uniform picture of whether leverage has an impact other company's dividend payout or not.

\section{Return on Assets}

Return on Assets is selected as a third variable that defines the company contribution in assets and find that how much company make profit against assets investment. In order to get more profit, the firms keep low rate of dividend to increase the revenues of the company for internal use. On the other side, if the companies want to obtain more earnings against their asset utilization so the companies pay out high rate of dividend to stockholders in order to increase the company image [53].

\section{E. Firm Size}

Fourth variable of this study is firm size, which explains the firm's dividend policy. Large organizations will general be more develop and have simple access to the capital market [53] .According to Vogt, 1994 "The firm size will reduce their reliance on internal funding, so the company will provide high dividend payments".

\section{F. Free Cash Flow}

Cash outflow is also called dividend payments. It means that the firm has financial position, so the firm is capable to pay higher dividend. It also becomes a mean of dispute between managers and shareholders because managers want to have more cash for investments to increase earnings figure and revenue of the firm. On the other hand, shareholders want to get more cash for the distribution of dividend [53].

\section{G. Managerial Ownership and Dividend Policy}

[53] researched that a negative and significant association found between managerial ownership and dividend policy. The results of [53] also showed that if the company ownership level is high then the company wants to keep more reserves to enhance the level of internal funds efficiently and effectively as compared to external funs by giving more dividends to shareholders. While less ownership level, the firm have a tendency to be distribute more dividend to accomplish bright future and get sound financial position of the company.

\section{H. Debt Policy and Dividend Policy}

[18] portrayed that there has a negation relationship between debt policy and dividend policy, which means if the company has more debts, then the company is not able to pay high rate of dividend.

\section{Influence of ROA and Dividend Policy}

According to [18] directed that the firms' ROA has a positive impact on the dividend policy, means that the firms with high profits show an increase in the tendency to pay dividends more than less profitable companies.

\section{J. Firm Size and Dividend Policy}

There has a negative relationship between size and dividend policy, that implies the reaction of small 
company's stock prices for dividend deceleration is higher as compared to the response of larger companies [30]. But [28] does not agree with the results of [30] in which the researcher mentioned the reality that the firm size has positively associated with a dividend policy that is also suggested by [18].

\section{K. Free Cash Flows on Dividend Policy}

Sakir and Adil, in 2014 results determined positive effect of free ash flow on dividend policy of manufacturing companies. Free cash flow genuinely influences the dividend policy since the fundamental factor that decides the extent of the dividend is the measure of funds available, the larger the funds available in the organization, more fund will be relegated to the circulation of profit, and the other way around. This is like the free cash flow theory, specifically, when the organization has overabundance money, at that point extends that have a positive net value (NPV) stated by [49] Be that as it may, it is better for the managers to return overabundance trade to investors out the type of dividend payment with the end goal to amplify wealth of shareholders.

This theoretical framework followed the different theories regarding dividend policy like agency theory, Modigliani \& Miller theory and packing theory to investigate that which one theory is closely connected based on these theories some of concepts/variables were taken.

\section{Hypotheses}

There are following hypotheses which are mentioned below:

H1: There is a significant influence and positive of Managerial Ownership on Dividend Policy

$\mathrm{H} 2$ : There is a positive and significant influence of the Debt Policy on Dividend Policy.

H3: There is a significant and positive influence of Return on Asset on Dividend Policy.

H4: There is a positive and significant influence of the size of the Company on Dividend Policy.

H5: There has a significant and positive influence of the Company Cash Flow and Dividend Policy

\section{RESEARCH METHODOLOGY}

The current study based on descriptive to describe the characteristics of each variable and quantitative in nature because existing variables were taken based on literature review and also to test the effect of variables statistically and by applying ratio analysis techniques to collect the data in the numeric form. The secondary source used to collect data of this study with the help of reviewing annual reports of pharmaceutical's companies from the period of 2013 to 2017 (panel data). Pakistan Stock Exchange (PSX) has taken as a population-based on all financial and non-financial firms in which the data has been collected from Pharmaceutical sector as a sample size by applying census sampling technique because all the pharmaceutical's companies (12 companies) considered in this study in out of 577 listed companies. The list of companies are mentioned below: Fixed effect model, panel VAR model, and regression model have applied to investigate the influence of independent variables on dependent variable through the statistical package for social science (SPSS) tool. The multiple regression model has been followed in the regression analysis. The formula of multiple regression is mentioned below:

$$
D \mathrm{P}=\beta 0+\beta 1(\mathrm{MO})+\beta 2(\mathrm{DB})+\beta 3(\mathrm{ROA})+\beta 4(\mathrm{FS})+\beta 5
$$

(FCF)

Where:

DP: Dividend Policy

MO: Managerial Ownership

DB: Debt Policy

ROA: Return on Assets

FS: Firm Size

FCF: Free Cash Flow

TABLE 1: VARIABLES OF THE STUDY

\begin{tabular}{ccc} 
Variables of the Study & Formulas/Determination & Sources \\
\hline Dependent Variable & & \\
Dividend Policy & Dividend /Total Number of & \\
Dividend Per Share & Shares
\end{tabular}
(DS)

Dividend Yield (DY)

Managerial Owner
Dividend Payout
Ratio (DP) (DP)

Independent Variables Ship (MO)

Annual Dividend Per Share/Price Per Share

Sakir \& Adil, 2014

\section{Dividend /Net Income}

Number of shares held by directors and members of the board / total outstanding shares

Debt Policy (DB)

Book value of total debt/ Book value of total assets

Vo \&

Nguyen,(2014)

ROA

Net Income /Total Assets

Vo \&

Nguyen,(2014)

Firm Size (FS)

Cash Flow (CF)
Log of Total Assets

Cash flow Net operating income plus depreciation

Vo \&

Nguyen,(2014)
VII. Results OF The Study

TABLE 2: UNIT ROOT TEST

\begin{tabular}{ccc}
\hline Variables & Prob (level) & Prob. (First diff) \\
\hline DP & -7.213357 & 0.0000 \\
FCF & -7.673800 & 0.0000 \\
FS & -7.927797 & 0.0000 \\
LEV_DP & -6.574675 & 0.0000 \\
MO & -10.39045 & 0.0000 \\
ROA & -8.596087 & 0.0000 \\
\hline
\end{tabular}

From this table we can see that all the necessary variables are stationary at first level difference so there is no problem of different levels of stationarity. Now we can go for panel co-integration model.

TABLE 3: KAO RESIDUAL COINTEGRATION TEST

Kao Residual Cointegration Test

Series: DP MO LEV_DP ROA FS FCF

Null Hypothesis: No cointegration

t-Statistic Prob

ADF

$-4.867869$

0.0000 
From the given table as one can see that probability value is less than 0.05 we will reject the null hypotheses and accept the alternative hypotheses. For further analysis, we will proceed to the panel var model which indicates that which model will be appropriate for this, i.e fixed effect model or random effect model.

Panel VAR Model: For panel VAR model first, we run the fixed effect model and then random effect model because we want to check that which model is appropriate. So far Hausman` test can give the answer to this question.

TABLE 4: HAUSMAN TEST

\begin{tabular}{lccc}
\hline $\begin{array}{l}\text { Correlated Random Effects - Hausman Test } \\
\text { Equation: Untitled } \\
\text { Test cross-section random effects }\end{array}$ & & \\
\multicolumn{1}{c}{ Test Summary } & $\begin{array}{c}\text { Chi-Sq. } \\
\text { Statistic }\end{array}$ & $\begin{array}{c}\text { Chi-Sq. } \\
\text { d.f. }\end{array}$ & Prob. \\
Cross-section random & 48.279438 & 10 & 0.0000 \\
\hline
\end{tabular}

The probability value is less than 0.05 so we will reject the null hypothesis and accept alternative hypothesis which implies the fixed effect model is appropriate.

TABLE 5: FIXED EFFECT MODEL

\begin{tabular}{|c|c|c|c|c|}
\hline \multicolumn{5}{|c|}{$\begin{array}{l}\text { Dependent Variable: DP } \\
\text { Method: Panel Least Squares }\end{array}$} \\
\hline Variable & Coefficient & Std. Error & t-Statistic & Prob. \\
\hline C & 48.50409 & 30.18208 & 1.607050 & 0.1391 \\
\hline DP(-1) & 0.507868 & 0.171768 & 2.956710 & 0.0144 \\
\hline DP(-2) & -0.250507 & 0.135931 & -1.842901 & 0.0951 \\
\hline MO(-1) & -0.002057 & 0.000852 & -2.414723 & 0.0364 \\
\hline MO(-2) & -0.002501 & 0.001105 & -2.263682 & 0.0471 \\
\hline LEV_DP(-1) & 1.239663 & 0.425634 & 2.912511 & 0.0155 \\
\hline LEV_DP(-2) & 1.389147 & 0.685245 & 2.027227 & 0.0701 \\
\hline ROA(-1) & -1.913582 & 1.071744 & -1.785484 & 0.1045 \\
\hline ROA(-2) & 3.502580 & 1.279702 & 2.737027 & 0.0209 \\
\hline FS(-1) & 2.579284 & 0.516277 & 4.995934 & 0.0005 \\
\hline FS(-2) & 0.356943 & 0.474382 & 0.752438 & 0.4691 \\
\hline FCF(-1) & -0.816494 & 0.721618 & -1.131476 & 0.2843 \\
\hline FCF(-2) & -1.299356 & 0.562269 & -2.310915 & 0.0434 \\
\hline
\end{tabular}

From the given table we can interpret the model. As we are having different variables. The dependent variable is dividend policy which indicates that from the base year of dividend policy it is significant as for the current year it is insignificant, managerial ownership is significant for the base year and it is also significant for the current year as well, leverage debt policy is significant for the base year and it is insignificant for the current year, return on assets is insignificant for the base year and so far it is significant for the current year. Firm size indicates that for the base year it is significant while it is insignificant for the current year. Last but not the least free cash flow is insignificant for the base and current year as well.
TABLE 6: DEPENDENT VARIABLE: DP

\begin{tabular}{lllll}
\hline Dependent Variable: DP & & & \\
\hline Variable & Coefficient & Std. Error & t-Statistic & Prob. \\
\hline C & $-4.79 \mathrm{E}-15$ & $1.85 \mathrm{E}-15$ & -2.595560 & 0.0124 \\
MO & $6.00 \mathrm{E}-20$ & $2.41 \mathrm{E}-20$ & 2.491311 & 0.0162 \\
LEV_DP & $6.28 \mathrm{E}-17$ & $3.05 \mathrm{E}-17$ & 2.059356 & 0.0448 \\
ROA & 0.333333 & $5.88 \mathrm{E}-17$ & $5.66 \mathrm{E}+15$ & 0.0000 \\
FS & 0.333333 & $2.43 \mathrm{E}-16$ & $1.37 \mathrm{E}+15$ & 0.0000 \\
FCF & 0.333333 & $1.24 \mathrm{E}-16$ & $2.68 \mathrm{E}+15$ & 0.0000 \\
R-squared & 0.86325 & & & \\
F-statistic & $2.03 \mathrm{E}+31$ & & & \\
Prob(F-statistic) & 0.000000 & & & \\
\hline
\end{tabular}

The value of $\mathrm{R}$-square indicates the coefficient of correlation between variables see table 7 . The R-square value is (.8632) mean $86.32 \%$ is reliable means that independent variables explained dividend policy by the rate of $86.32 \%$.

\section{DISCUSSION AND CONCLUSION}

The focal point of present research is to show those factors that affect dividend policy by taking pharmaceutical's companies listed on PSE from 2013 to 2017. The results found that hypothesis one indicates that there has a positive and significant effect of managerial ownership on dividend policy. Similar results are consistent with the results of [41], [22], [48], [42] and [51]. It showed that higher percentage of management ownership (board of directors and CEO) lead toward higher payment of dividend will be given to shareholders by the firm. The second hypothesis is accepted to show the positive and significant effect of debt policy (Leverage) on dividend policy with supporting results of [7], same as in Nigeria by applying Hausman panel test rule. According to Sindhu, Hashmi, \& UlHaq [54] there is significant and positive relationship in between leverage and dividend policy based on cash flow theory, the stated theory examined that net profit of the firm should be circulated among shareholders.

Third hypothesis demonstrates the connection among profitability and policy of profit sharing. The results of this demonstrated that profitability impacts profit sharing has a direct and significant effect. The results showed that the amount of profit sharing is increased due to increase in profitability. the ability of earning money called firm's profitability. Sturdiness and survival of an organization in a long haul rely upon the organization's capacity in increasing sufficient profit for playing out every one of the commitments and giving the suitable come back to stockholders. Organization resources play a vital role to get company's profit. when the utilization of resources will effective and efficient in manner so the company will be capable to gain more return against invested assets. The results of this study supported with the consequences of [10], [15], [42] and [6].

On the opposite side, $\mathrm{H} 4$ has a positive and significant influence of firm size on dividend policy, which indicates that with the expansion in firm size; there will be a positive change in profit distribution among shareholders [54].

Fifth hypothesis concluded that positive and significant association found between free cash flow dividend policy of non-financial firms listed on PSE. Results indicated that 
higher amount of funds will allocate more dividend for distribution for shareholders by the company and vice versa. Belkaoui [46] stated that when a company has excess amount of cash having positive net value then the firm must be funded. While the manager must distribute this excess amount among shareholders to increase wealth of shareholder. It also showed that dividend amount can eliminate agency cost, because it reduces the free cash flow available to managers. These results found that $\mathrm{H} 5$ is considered with the supporting results of [53].

\section{FUTURE RESEARCH DIRECTION}

The present study was limited to pharmaceutical's Companies in order to more generalize the results in future. Future researcher requires to be carried out other sectors of Pakistan Stock Exchange (PSE) by analyzing the other contextual factors relevant to the selected firm or sector.

\section{REFERENCES}

[1] Ahmed, H. and Javaid, A.Y. (2009), "The determinants of dividend policy in Pakistan", International Research Journal of Finance and Economics, Vol. 29, pp. 110-25.

[2] Al-Malkawi, H. N. (2007) "Determinants of Corporate Dividend Policy in Jordan: An Application of the Tobit Model" Journal of Economic and Administrative Sciences, Vol. 23(2): 44-70.

[3] Al Shabibi, B. K., \& Ramesh, G. (2011). An empirical study on the determinants of dividend policy in the UK. International Research Journal of Finance and Economics, 80(12), 105-124.

[4] Al-Kuwari, D. (2009). Determinants of the dividend policy of companies listed on emerging stock exchanges: the case of the Gulf Cooperation Council (GCC) countries.

[5] Amidu, M. \& Abor, J. (2006) "Determinants of Dividend Payout Ratios in Ghana" The Journal of Risk Finance, Vol.7 (2): 136-45.

[6] Asadi, G. H., \& Azizi, B. S. (2008). The Relationship between Carporation Income and Liquidity and Its Influence on Dividend.

[7] Amahalu, N. N., Okoye, E. I., Nweze, C. L., \& Chinyere, O. J. (2016). Effect of Financial Leverage on Dividend Policy of Quoted Conglomerates (2010-2015).

[8] Amahalu, N., Abiahu, M. F. C., Chinyere, O., \& Nweze, C. (2018). Effect of Accounting Information on Market Share Price of Selected Firms Listed on Nigeria Stock Exchange.

[9] Ayano, D. F., \& Ponnala, V. (2016). Determinants of commercial banks financial performance in Ethiopia. Unpublished Master's thesis, Adis Ababa: Adis Ababa University.

[10] Bahramfar N, Mehrani K (2004). Relation profit of each stock, dividend and enterprise in accepted companies in exchange stock of Tehran, J. Acc. Audit. Rev. 36:27-46.

[11] Bell, L., \& Jenkinson, T. (2002). New evidence of the impact of dividend taxation and on the identity of the marginal investor. The Journal of Finance, 57(3), 1321-1346.

[12] Black, F. (1976), "The dividend puzzle", Journal of Portfolio Management, Vol. 2 No. 1, pp. 1-22.

[13] Brealey, R. A., Allen, F. \& Myers, S. C., 2008. Principles of Corporate Finance. 9 ed. New York, NY: McGraw-Hill/Irwin.

[14] Bushra, A. \& Mirza, N., 2015. The Determinants of Corporate Dividend Policy in Pakistan. The Lahore journal of economics, 20(2), p. 77-98

[15] Chalaki P. (2005). Impact of accounting profit and operational cash flows on dividend in accepted companies in exchange stock of Tehran, Thesis M.A. in accounting course, University of Tarbiat Modares. p. 31-47.

[16] Chen, J. \& Dhiensiri, N. (2009) "Determinants of Dividend Policy: The Evidence from New Zealand" International Research Journal of Finance and Economics, Issue 34: 18-28.

[17] Crutchley, C. \& Hansen, R. (1989) "A Test of the Agency Theory of Managerial Ownership, Corporate Leverage and Corporate Dividends" Financial Management, Vol.18: 36-46.

[18] Cristea, C., \& Cristea, M. (2017). Determinants of corporate dividend policy: evidence from romanian listed companies. In MATEC Web of Conferences (Vol. 126, p. 04009). EDP Sciences.
[19] Davies, T., \& Pain, B. (2002). Business Accounting \& Finance. Berkshire: McGraw-Hill.

[20] Droughty, M. (2000). The Joy of Money. London: Simon \& Schuster Ltd.

[21] Frankfurter, G. M., \& Wood Jr, B. G. (1997). The evolution of corporate dividend policy. Journal of financial education, 16-33.

[22] Foroughi, M., \& Fooladi, M. (2011). Corporate ownership structure and firm performance: evidence from listed firms in Iran

[23] Easterbrook, F. H. (1984) "Two Agency-Cost Explanations of Dividends" American Economic Review, Vol.74 (4): 221-30.

[24] Gustav Hellström and GairatjonInagambaev (2012) Determinants of Dividend Payout Ratio: A Study of Swedish Large and Medium Caps. Umeå School of Business and Economics Journal.Umeå University SE-901 87 Umeå, Sweden.

[25] Gill, A., Biger, N., \& Tibrewala, R. (2010). Determinants of dividend payout ratios: evidence from United States. The Open Business Journal, 3(1).

[26] Glen, J., Karmokolias, Y., Miller, R. and Shah, S. (1995) "Dividend Policy and Behavior in Emerging Markets" IFC Discussion Paper No. 26.

[27] Gugler, K. (2003) "Corporate Governance, Dividend Payout Policy and the Interrelation between Dividends, R\&D and Capital Investment" Journal of Banking and Finance, Vol. 27: 1297-1321.

[28] Jabbouri, I. (2016). Determinants of corporate dividend policy in emerging markets: evidence from MENA stock markets. Research in international business and finance ,37, 283-298.

[29] Jensen, M. C. (1986). Agency Costs of Free Cash Flow, Corporate Finance and Takeovers. The American Economic Review, 76(2), 323-329.

[30] Jin, Z., Yang, H., \& Yin, G. G. (2013). Numerical methods for optimal dividend payment and investment strategies of regimeswitching jump diffusion models with capital injections. Automatica, 49(8), 2317-2329.

[31] Kaleem, A., \& Salahuddin, C. (2006). Impact of dividend announcement on common stock prices at Lahore Stock Exchange (Pakistan). South Asian Journal of Management, 13(2), 86.

[32] Kania, Sharon L. Longwood \& Bacon Frank W. (2005), What Factors Motivate The Corporate Dividend Decision?, Asbbs EJournal, Volume 1, No.1, Pp. No. 97-107.

[33] Kinfe, T. (2011). Determinants of dividend payout: an empirical study on banking industry in Ethiopia, 2006-2010. Unpublished Master Thesis). Addis Ababa University.

[34] Kaźmierska-Jóźwiak, B. (2015). Determinants of dividend policy: evidence from polish listed companies. Procedia economics and finance, 23, 473-477.

[35] Lasfer, M. A. (1995). Agency costs, taxes and debt: The UK evidence. European Financial Management, 1(3), 265-285.

[36] Lintner, J. (1956). "Distriobution of Incomes of Corporations among Dividend, Retained Earning and Tax", American economic Review.

[37] Lonie, A. A., Abeyratna, G., Power, D. M., \& Sinclair, C. D. (1996) The stock market reaction to dividend announcements: A UK study of complex market signals. Journal of Economic studies, 23(1), 3252 .

[38] McCluskey, T., Burton, B. M., Power, D. M., \& Sinclair, C. D. (2006). Evidence on the Irish stock market's reaction to dividend announcements. Applied Financial Economics, 16(8), 617-628.

[39] Mehta, A. (2012). An empirical analysis of determinants of dividend policy-evidence from the UAE companies. Global Review of Accounting and Finance, 3(1), 18-31.

[40] Miller, M.H. and Modigliani, F. (1961), "Dividend policy, growth, and the valuation of shares", Journal of Business, Vol. 34 No. 4, pp. 411-33.

[41] Mitton, T. (2004). Corporate governance and dividend policy in emerging markets. Emerging Markets Review, Vol. 5 No. 4, pp. 409426.

[42] Mohamadi, L. H., \& Amiri, H. (2016). Investigation the effect of ownership structure, financial [42] leverage, profitability and Investment Opportunity on Dividend Policy. International Journal of Humanities and Cultural Studies (IJHCS) ISSN 2356-5926, 22792288.

[43] Naceur, S. B., Goaied, M. and Belanes, A. (2005) "A Reexamination of Dividend Policy: A Dynamic Panel Data Analysis".

[44] Naeem, S. \& Nasr, M. (2007) "Dividend Policy of Pakistani Firms: Trends and Determinants" International Review of Business Research Papers, Vol. 3(3): 242 Studies from 1995 to 1996. Indonesian Journal of Accounting and Finance, 2(2), 103-123.

[45] Rasaeeyan, A., Rasekhi, S., Naghizadeh, B., \& Kashanipoor, M. (2010). Financial limitation and sensitivity of cash flow to investment in Tehran's stock exchange. Accounting improvement, 2nd period, 2nd issue, 51-74. 
[46] Riahi-Belkaoui, A. (1998). The effects of the degree of internationalization on firm performance. International Business Review, 7(3), 315-321.

[47] Riahi-Belkaoui, A. (2003). Intellectual capital and firm performance of US multinational firms: a study of the resource-based and stakeholder views. Journal of Intellectual capital, 4(2), 215-226.

[48] Nishat, M. \& Bilgrami, N. (1994) "Who pays dividend - An exploratory analysis of firms listed with Karachi stock market" AERC Discussion Paper 187.

[49] Nuhu, E. (2014). Revisiting the determinants of dividend payout ratios in Ghana. International Journal of Business and Social Science, 5(8).

[50] Nuringsih, K. (2005). Analysis of Effect of Managerial Ownership, Debt Policy, ROA, and Size of Corporate Dividend Policy:

[51] Rozeff, M. S. (1982). Growth, beta and agency costs as determinants of dividend payout ratios. Journal of financial Research, 5(3), 249259.

[52] Frankfurter, G. M., \& Wood Jr, B. G. (1997). The evolution of corporate dividend policy. Journal of financial education, 16-33.

[53] Sakir, A., \& Fadli, M. (2014). Influence of managerial ownership, debt policy, profitability, firm size, and free cash flow on dividend policy. Delhi Business Review, 15(1).

[54] Sindhu, M. I., Hashmi, S. H., \&UlHaq, E. (2016). Impact of ownership structure on dividend payout in Pakistani non-financial sector. Cogent Business \& Management, 3(1), 1272815

[55] Smith, C. J. \& Watts, R. L. (1992) "The Information Opportunity Set and Corporate Financing, Dividend and Compensation Policies" Journal of Financial Economics, Vol. 32(3): 263-92.

[56] Soter, D., Brigham, E., \& Evanson, P. (1996). The Dividend Cut "Heard 'round the World": The Case of FPL. Journal of Applied Corporate Finance, 9(1), 4-16.

[57] Uddin, H. Chaudhary. (2003). Effect of Dividend Announcement on Shareholders' Value: Evidence from Dhaka Stock Exchange.

[58] Vo, D. H., \& Nguyen, V. T. Y. (2014). Managerial ownership, leverage and dividend policies: Empirical evidence from Vietnam's listed firms. International Journal of Economics and Finance, 6(5), 274.

[59] Woolridge, J. R., \& Ghosh, C. (1985). Dividend cuts: do they always signal bad news?. Midland Corporate Finance Journal, 3(2), 20-32.

[60] Zameer, H., Rasool, S., Iqbal, S. \& Arshad, U., 2013. Determinants of Dividend Policy: A Case of Banking Sector in Pakistan. MiddleEast Journal of Scientific Research, 18(3), pp. 410-424.

[61] Zuluaga, A. P., Vega-Arreguín, J. C., Fei, Z., Ponnala, L., Lee, S. J., Matas, A. J., \& Rose, J. K. (2016). Transcriptional dynamics of Phytophthorainfestans during sequential stages of hemibiotrophic infection of tomato. Molecular plant pathology, 17(1), 29-41. 